\title{
POPULATION DYNAMICS OF PROTOZOAN ECTOPARASITES IN SOME CAT FISHES INHABITING DOMRI RESERVOIR, BEED DISTRICT (M.S.)
}

\author{
P. B. Sirsat \\ Department of Zoology \\ Mrs. K. S. K. College, Beed-431122 (M.S.), India
}

\section{Review Paper}

Received: 27.10.2021

Revised: 10.11.2021

Accepted: 22.11.2021

\begin{abstract}
The present study was conducted to find out the prevalence and intensity of protozoan ectoparasites of freshwater catfishes. Total four species of protozoan parasites were collected from 294 fishes. Total three ectoparasites were observed during study period, July 2020 to June 2021. Among the ectoparasites, Ichthyoptherius is the most prevalent ectoparasites followed by Trichodina and Myxobolus. Among the infected fishes, Wallago attu (48.43\%) harboured maximum number of ectoparasites followed by Ompok pabda (40.27\%), Mystus cavasius (37.93\%), and Mystus vittatus (32.78\%). Due to the presence of these parasites, the physiological activities of the host fishes are hindered and their developmental growth is retarded which cause economic loss to the fishery industry.
\end{abstract}

Keywords: Prevalence, Intensity, Protozoan ectoparasite, Catfish.

\section{INTRODUCTION}

Fishes are aquatic vertebrates having streamlined body (Verma and Prakash, 2020). These are the important source of animal protein (Verma, 2007) to ensure food security for human and also play an important role in national economy as it provides employment opportunity (Prakash et al, 2021a). The fishes get infection from various kinds of parasites frequently (Peddinti et al., 2021). Diseases affect the normal health conditions and cause reduction of growth, abnormal metabolic activities and even death. Aquaculture contributed over 95\% of the total inland fish production during 2014-15 as against 34\% during 198485. It was so, even after the fact that less than $40 \%$ of available ponds and tanks in the country (total available estimated resource 24.41 lakh ha) are estimated to being scientifically utilized at present. Although fish production has increased manifold in India but freshwater productivity especially inland culture fishery decreases due to various parasites which affect the metabolic activities, normal health conditions and even death of culturable fishes (Prakash et al., 2021b). Because of increased stocking density of fishes in fishery ponds, fish pathogens can easily transmit from one fish to another (Prakash, 2021). Since these pathogens affect the reproductive potential of host fishes, a parasitic disease reduces the fish production, profitability, and market as well as nutritive value (Prakash and Singh, 2020). The parasites may cause mortality and morbidity in cultivable fishes resulting in great loss in fish production as well as economic loss to be culturists (Prakash and Verma, 2017). Parasitic diseases are the limiting factors in fish culture, because of increased density of fish in lentic water bodies where the fish pathogens can easily transmit from one fish to another. These pathogens may cause fish mortality in cultural fishes where the entire fish population of water body may be killed, resulting the great economic loss of fish farmers (Prakash and Verma, 2020). Thus, parasites of fish are one of the major problems to fish health (Verma et al., 2006, 2007; Narayan et al., 2021).

Among the various parasites, parasitic protozoa play an important role in the growth and development of fishes and

*Corresponding author: drprembst@gmail.com 
most hazardous threats to fish health. Protozoans are now a part of kingdom Protista (Verma, 2021). These parasites attack the fish and causes great loss of skin and gill epithelium. Even moderate infection of these parasites may cause a fatal disease, since the infected fish lose its appetite and stop feeding (Meyer, 1991). Extensive works on the protozoan parasites of fish have been carried out by some worker (Aguilar et. al., 2017; Prakash and Verma, 2017 \& 2020; Prakash et al., 2021b). The distribution, incidence and intensity of infestation of fish parasites vary from one place to another (Wahab and Saidin, 2014). Studies on protozoan diseases of fishes particularly in Maharashtra State are fragmentary. Keeping in view, importance of parasitic infection to freshwater fishes, present study was designed to evaluate seasonal variation in prevalence, intensity, density and index of infection of protozoan parasites in freshwater cat fishes of Domri reservoir of Beed district of Maharashtra.

\section{MATERIALS AND METHODS}

Domri reservoir is situated near the Ukhanda village Tq. Patoda, district Beed. It is located on $18^{\circ}-54^{\prime}$ longitude and $75^{0}-34^{\prime}$ latitude. It covers about 2371aq $\mathrm{km}$. water spread area. It is constructed during the year 1996. It is $16 \mathrm{~km}$ away from Beed city. Its water is used in agriculture and also by animal as well as man for different purposes. Due to the pollution as well as entry of sewage, waste water or matter and interaction between all these factors some notable changes were recorded in this aquatic ecosystem (Jogdand and Sirsat, 2012).
Fresh water cat fishes Ompok pabda, Wallago attu, Mystus cavasius, and Mystus vittatus were randomly collected in every month from Domri reservoir during. July 2020 to June 2021 and were observed for parasitic infection. Live infected fishes were brought to the laboratory and kept in small plastic aquaria containing freshwater.

For examined the ectoparasitic protozoan parasites, the mucus of gills and body surface were collected by pipette, dropper and needle on a slide. With a drop of $0.5 \mathrm{~N} \mathrm{NaCl}$ solution, mucus smear slide were prepared and air dried. These air dried smear slides were placed in absolute methyl alcohol for 8-10 minutes than stained with the Geimsa stain for 25 minutes. Washed the slide in distilled water to remove excess stain, and then allow the smear to dry and mount in DPX. The collected parasites were identified under a compound light microscope with the help of standard literature (Lucky,1971; Kabata, 1985; Mukherjee et al., 2019). Prevalence of parasitic infection were calculated by following the formula (Margolis et al., 1982).

$$
\begin{aligned}
& \text { Total no. of infected fishes } \\
& \text { Prevalence \% = -------------------------------------X } 100 \\
& \text { Total no. of fish examined } \\
& \text { Total no. of parasites collected } \\
& \begin{array}{r}
\text { Intensity of Infection =---------------------------------------- } \\
\text { Total no. of infected fish examined }
\end{array}
\end{aligned}
$$

Table 1: Protozoan ectoparasites of fishes in Domri reservoir, Beed (M.S.).

\begin{tabular}{|l|c|c|c|c|}
\hline Group & Genus & Type & Host & Infected organ \\
\hline Ciliate & $\begin{array}{c}\text { Trichodina, } \\
\text { Ichthyoptherius }\end{array}$ & Ectoparasite & $\begin{array}{c}\text { Wallago attu, } \\
\text { Ompok pabda } \\
\text { Mystus vittatus }\end{array}$ & Gills \& Skin \\
\hline Myxozoan & Myxobolus & Ectoparasite & $\begin{array}{c}\text { Mystus cavasius, } \\
\text { Wallago attu }\end{array}$ & Gills \\
\hline
\end{tabular}

Table 2: Prevalence of Protozoan Ectoparasites in different freshwater catfishes.

\begin{tabular}{|l|c|c|c|c|}
\hline Host Fish & $\begin{array}{c}\text { No of Fishes } \\
\text { Examined }\end{array}$ & $\begin{array}{c}\text { Total no. of } \\
\text { infected fishes }\end{array}$ & $\begin{array}{c}\text { Total No. of } \\
\text { Parasite collected }\end{array}$ & Prevalence (\%) \\
\hline Wallago attu & 64 & 22 & 31 & 48.43 \\
\hline Ompok pabda & 72 & 25 & 29 & 40.27 \\
\hline Mystus cavasius & 58 & 19 & 22 & 37.93 \\
\hline Mystus vittatus & 61 & 15 & 20 & 32.78 \\
\hline Total & 255 & 72 & 102 & 40.00 \\
\hline
\end{tabular}


Table 3: Prevalence, Intensity and Density of Ectoparasitic Protozoan in different freshwater cat fishes in Domri reservoir, Beed (M.S.).

\begin{tabular}{|c|c|c|c|c|c|c|c|}
\hline Host Fishes & $\begin{array}{l}\text { No. Fishes } \\
\text { Examined }\end{array}$ & $\begin{array}{l}\text { Total No. } \\
\text { of fish } \\
\text { infected }\end{array}$ & Name of Parasite & $\begin{array}{l}\text { Number of } \\
\text { Fishes } \\
\text { Infected } \\
\text { with each } \\
\text { parasite }\end{array}$ & $\begin{array}{c}\text { Total No. } \\
\text { of Parasite } \\
\text { collected }\end{array}$ & $\begin{array}{c}\text { Prevalence } \\
\%\end{array}$ & Intensity \\
\hline \multirow[t]{3}{*}{ Wallago attu } & \multirow[t]{3}{*}{64} & \multirow[t]{3}{*}{22} & Trichodina, & 10 & 12 & 15.62 & 1.20 \\
\hline & & & Ichthyoptherius & 08 & 13 & 12.50 & 1.62 \\
\hline & & & Myxobolus & 04 & 06 & 9.37 & 1.50 \\
\hline \multirow[t]{3}{*}{ Ompok pabda } & \multirow[t]{3}{*}{72} & \multirow[t]{3}{*}{25} & Trichodina, & 11 & 11 & 15.27 & 1.00 \\
\hline & & & Ichthyoptherius & 09 & 10 & 12.50 & 1.11 \\
\hline & & & Myxobolus & 05 & 08 & 6.94 & 1.60 \\
\hline \multirow[t]{2}{*}{ Mystus cavasius } & \multirow[t]{2}{*}{58} & \multirow[t]{2}{*}{19} & Trichodina, & 09 & 12 & 15.51 & 1.33 \\
\hline & & & Ichthyoptherius & 10 & 10 & 17.24 & 1.00 \\
\hline \multirow[t]{2}{*}{ Mystus vittatus } & \multirow[t]{2}{*}{61} & \multirow[t]{2}{*}{15} & Trichodina, & 08 & 12 & 13.11 & 1.50 \\
\hline & & & Ichthyoptherius & 07 & 08 & 11.47 & 1.14 \\
\hline
\end{tabular}

Total 255 freshwater catfishes (Wallago attu, Ompok pabda, Mystus cavasius and Mystus vittatus) were examined for indentifying the parasitic protozons. Out of 255 examined fishes, only 102 fishes were found infected with protozoan parasites. Total three ectoparasites namely Trichodon, Ichthyoptherius and Myхobolus were identified (Table 1).

Among the infected fishes, Ompok pabda harboured maximum number of ectoparasites (25) followed by Wallago attu (22), (23), Mystus cavasius (19) and Mystus vittatus (15) (Table1\&2). Ectoparasitic protozoans are commonly found on the gills and skin of host fishes. The infected fishes show following clinical sign: swim rapidly and rub their bodies against the substratum; the fish come on the surface for gasping the oxygen and become lethargic and eventually stop feeding. The highest prevalence rate was observed in Wallago attu (48.43\%) followed by Ompok pabda (40.27\%), Mystus cavasius (37.93\%), and Mystus vittatus (32.78\%). Among the ectoparasites, Ichthyoptherius is the most prevalent ectoparasites followed by Trichodina and Myxobolus (Table 3). The result of the present investigation correlated with minor differences to the finding of other researchers (Kabata, 1985; Mukherjee et al.,
2019; Prakash et al, 2021b). The prevalence and intensity of parasites depends on many factors such as nature of parasites and its life cycle, host, feeding habits and the physico-chemical factors of water body where the fish inhabited. Ectoparasitic prevalence increases when water temperature and hardness decreases. Due to the presence of these parasites, the physiological activities of the host fishes are hindered and their developmental growth is retarded which cause economic loss to the fishery industry.

\section{CONCLUSION}

The result of present study indicated that the prevalence, intensity and density of infection of protozoan parasite were highest in Wallago attu followed by Ompok pabda, Mystus cavasius and Mystus vittatus. The high organic load and poor quality of aquatic environmental has great impact on the abundance of pathogens either directly or indirectly. Therefore, it is concluded that the healthy water quality should be maintained properly to avoid the appearance of parasites in the water bodies.

\section{REFERENCES}

1. Aguilar, R.A. and Ortega, A.G. I. (2017). A checklist of ciliate parasites (Ciliophora) of fishes from Mexico. Zootaxa. 4027 (2): 270-280. 
2. Jogdand, S.K. and Sirsat, P.B. (2012). An assessment of phytoplankton from Domri Reservoir district Beed (M.S.) India. Trends in Life Sciences. 1(2):13-15.

3. Kabata, Z. (1985). Parasites and diseases of fish cultured in the Tropics. Taylor and Francis, London and Philadelphia.

4. Lucky Z. (1971). Methods for the diagnosis of fish diseases. Amerind Publishing Co. Pvt. Ltd. New Delhi, New York.

5. Margolis, L., Esch, G.W., Holmer, J.C., Kuris, A.M. and Schad, G.A. (1982). The use of ecological terms in parasitology.. Journal of Parasitoogyl., 68: 131-133.

6. Meyer, F.P. (1991). Aquaculture disease and health management. J.Anim. Sci. 69:4201-4208.

7. Mukherjee, D., Soni, M., Sanyal, K. B. and Dash, G. (2019). Prevalence of Ectoparasitic Infestation in Indian Major Carps During Winter at Different Blocks of South 24-Parganas District, West Bengal, India. Journal of Fisheries Science.1(1): 7-14.

8. Narayan, A., Yadav R., Singh D. and Rajpoot V. (2021). Prevalence of Piscean cestode, Mystoides chhaviensis in freshwater fish from Bundelkhand region of Uttar Pradesh, India. International Journal of Biological Innovations. 3(2):407-410.

9. Peddinti R.A., Thummala C., Khateef R. and Vankara A. (2021). Ectoparasitic community ecology of freshwater fishes of River Penna, YSR Kadapa District, Andhra Pradesh, India. International Journal of Biological Innovations. 3 (2): 241-256. https://doi.org/ 10.46505/ IJBI.2021.3201

10. Prakash, S. (2021). Mycoses infection in some fresh water carps of tarai region of Balrampur. International Journal of Scientific Research in Biological Sciences. 8(1): 1-4.

11. Prakash, S. and Singh, D. (2020). Seasonal variation of helminth Parasites in fresh water fishes of Sauwan Nallah of Balrampur, U.P., India. International Journal of Scientific Research in Biological Sciences. 7(4): 26-29.
12. Prakash, S. and Verma, A.K. (2020). Seasonal variation in prevalence of ectoparasitic infection in Indian major carps at Balrampur, U.P., India. Uttar Pradesh Journal of Zoology. 41(10):121127.

13. Prakash, S. and Verma, A.K. (2017).Incidence of parasites in Labeo rohita (Hamiliton) at Balrampur (U.P.). Life Science Bulletin. 14(2): 181-183.

14. Prakash, S., Yadav, D.K. and Jaiswal, L. (2021a). Population dynamics of crustacean parasites of fresh water fishes at Bahraich, U.P. International Journal of Zoology and Applies Biosciences 6(1):15-18.

15. Prakash, S., Yadav, D.K. and Jaiswal, L. (2021b). Protozoan parasites of fishes from Chittorgarh reservoir, Balrampur district (U.P.). International Journal of Zoology and Applied Biosciences. 6(6):110-113.

16. Verma, A.K. (2017). A Handbook of Zoology. Shri Balaji Publications, Muzaffarnagar. 5th edn. 648p.

17. Verma, A.K. (2021). Protozoans: Animals or Protists? International Journal of Life Sciences. 9(1): 41-44.

18. Verma A.K. and Prakash S. (2020). Status of Animal Phyla in different Kingdom Systems of Biological Classification. International Journal of Biological Innovations. 2 (2): 149-154. https://doi.org/ 10.46505/ IJBI.2020.2211

19. Verma, A.K., Singh A.K. and Srivastava V.C. (2007). On a New Hymenolepid cestode, Coronacanthus ashoki N. sp. from the Mole, Crocidura murianus (Linn). Flora and Fauna. 13 (1): 148-150.

20. Verma, A.K., Singh A.K. and Srivastava V.C. (2006). A New Hymenolepid cestode, Podicipitilepis yamagutii N. sp. from the Nightingale, Eudynamis scolopaceus. Flora and Fauna. 12 (1): 111-113.

21. Wahab A. Rahman and Saidin, H. (2014). Relationship between sex and parasite intensity in four freshwater fish species from Tasik Merah, Perak, Peninsular Malaysia. World J. Zoology. 6(4):370-374. 